\title{
Comparison of Self-Regulated and Students' Learning Achievements by Using E-learning Based Schoology and Power Point on Biology Materia
}

\author{
Asmariati Purba ${ }^{1}$, Herbert Sipahutar ${ }^{2}$, Syahmi Edi $^{3}$ \\ Departement of Biology Education, Faculty of Mathematics and Natural Science, Universitas Negeri \\ Medan, Jl. Willem Iskandar Psr V Medan Estate-Indonesia (20221) ${ }^{1,2,3}$
}

\begin{abstract}
This study aims to investigate the comparison of self-regulated and learning achievements of students who are taught by using e-learning based schoology and power point media on human reproduction system in grade XI IPA SMA Negeri 1 Silimakuta. The research method which is applied is quasi experiment with the participans of all students of grade XI IPA are 160 students. The sample of research is determined by cluster random sampling technique mainly grade XI-1 is taught by using e-learning based schoology media and grade XI-2 is taught by using power point media. The research design which is used is pretest-posttest control group design. Data analysis technique used Independent Samples t Test. The results of the research shows that the students' self-regulated learning which is taught by using e-learning based schoology media is $88,33 \pm 0,482$ with the gain of $14,93 \pm 1,005$ while in the class power point is $83,33 \pm 0,682$ with the gain of $9,57 \pm 0,827$. Students' self-regulated learning which is taught by using e-learning based schoology media is significantly higher is $21,88 \%$ compared with by using power point media $\left(\mathrm{t}_{\text {count }} 4,124 ; \mathrm{P}=0.000\right)$. Students' learning achievements which is taught by using e-learning based schoology media is $85.44 \pm 1,018$ with the gain of $61,44 \pm 2,138$ while in the class power point is $72,53 \pm 1,448$ with the gain of $50,07 \pm 2,911$. Students' learning achievements which is taught by using e-learning based schoology media is significantly higher is $10,19 \%$ compared with by using power point media $\left(\mathrm{t}_{\text {count }} 3,145 ; \mathrm{P}=0.003\right)$. As a conclusion that the use of $\mathrm{e}$ learning based schoology media more contributes to improve self-regulated and learning achievements, especially in the material of the human reproduction system. Thus, researchers suggest that the use of e-learning based schoology media in the process of biology learning as one of the learning innovation efforts.
\end{abstract}

Keywords: E-learning, Schoology, Power Point, Self-Regulated Learning, Learning Achievements

\section{Introduction}

The use of technology nowadays has been widely done in various aspects of life including in education aspect. Digital technology in education can be used as a learning tool to 
help students to obtain the factual information and facilitate teachers in delivering the subject matter. One of the information technology in learning is e-learning. According to Horton (2003) E-learning is the use of internet and web technology to create learning experiences. While Hargis (2000) states the reason for using internet is because of wide information access, unlimited resources, students as active participants, the motivation influence from learning activities, students' discovery and cooperative learning. E-learning helps teachers in teachinglearning activities. By E-learning teaching, materials can be visualized in more dynamic and interactive forms so that students can be motivated to engage further in the learning process (Wahono, 2003). The use of E-learning today is not too difficult when viewed based on the rapid internet users. Based on the data obtained, the total of internet users in Indonesia in 2016 reached 132.7 million people $(51.8 \%)$, university student users 10.3 million $(7.8 \%)$ and students 8.3 million $(6.3 \%)$ (Isparmo, 2016).

Teachers as an educator must be able to improve the quality of learning, develop inovative learning and expand inovative learning resources by utilizing ICT to increase students' interests and motivation that will influence students' achievements especially on elusive materials.

The reproduction system is one of the most elusive biology material for elementary and tenth graders according to Ozcan et al (2014). In line with research conducted by Tekkaya et al (2001) stated that the material reproduction is one of the material that is difficult to learn by some students. Lazarowitz et al (1992) in Tekkaya et al (2001) and Cimer (2012) also found that Israeli high-school students had difficulties in learning of physiological process materials. The reason why students treat biology as a difficult lesson is the low interest and motivation to learn biology (Mavrikaki et al., 2012). To overcome student's learning difficulties, it is necessary to do learning innovation which can improve students' self-regulated and learning achievements such as the use of online e-learning media. According to Wood (2009), effective learning innovation can improve students' knowledge. It is in line with Eison (2010) who stated that the use of active learning can build students' interest and increase students' knowledge.

One of the learning innovations which can be used is the e-learning based schoology. Schoology is one of the Learning Management Systems (LMS) which provides facilities for teachers and students to interact each other and also exchange information via online. Schoology also enables students to download lesson material, presentation slides, video tutorials, work on exams, discussions and submission of task which is assigned by the teacher. According to Dziuban et al (2004) in Cepik et al (2016) one of the characteristics of blended learning is increasing the interaction between students with teachers, students with students, students with materials and students with other new material. Through the interaction among students in learning, it is expected to improve students' regulated learning to achieve learning objectives. Research Susanto et al (2011) stated that using blended learning method by schoology can increase students' self regulated learning 75.17\%. Similarly, Ansor (2015) found schoology media is more effective to improve students' mathematic self-regulated learning. Sicat et al (2015) also stated that there is significant differences of students' learning achievements among groups applying conventional method and those applying schoology. Likewise, Irawan et al (2017) stated that there is significant differences of students' learning achievements among those using blended learning based schoology and problem based learning.

Another media that can be used in the learning process is the power point. Power point is one part of simple e-learning that provides facilities in arranging an effective and easy multimedia presentation. Power points can be used to help convey an idea to be more 
interesting and clear its purpose by creating dynamic presentation slides. This media can display images with animation to facilitate the delivery of abstract material such as stages of the process of gametogenesis to students, so that students more easily understand the material being submitted by the teacher. Visualization of images is one way to be concrete something abstract that can be displayed through the use of power point media. This media is expected to increase student interest and motivate students to actively participate in learning so that students' learning outcomes can be achieved. There are various studies on the use of power points as learning media, such as research Srimaya (2017) found the motivation, activity and student learning outcomes increased after learning process using power point. Kafit Research (2009) using computer learning media can facilitate and improve the quality of learning, improve student learning motivation, support individual learning according to the ability of students, the material can be repeated as needed and able to improve students' achievements.

Based on the observations conducted in SMA Negeri 1 Silimakuta, the learning process has not applied e-learning optimally. Learning is done by lecturing method, it was done in biology lesson as well. This results in low self-regulated and learning achievements on students. Therefore, this study suggests to provide information for the teachers to be able to optimize the use of internet by utilizing e-learning based schoology and power point media as a learning innovation.

\section{Research Methods}

\subsection{Research Location, Population and Sample}

This research was conducted in grade XI IPA SMA Negeri 1 Silimakuta, Pendidikan Street, No.156 Saribu Dolok. This study was conducted since May to June 2017. The participans of this study were all students of grade XI IPA of SMA Negeri 1 Silimakuta totalling 160 students in which grade XI-1 and XI-2 were the samples determined by cluster random sampling technique (Sugiyono, 2015 ).

\subsection{Research Design And Variables}

This research is quasi experiment with pretest-postest control group design. Grade XI-1 were taught by using e-learning based schoology and grade XI-2 were taught by using power point. The independent variables are E-learning based schoology and power point, while the dependent variables are students' self-regulated and learning achievements.

\subsection{Instruments and Data Analysis}

This research instrument is a questionnaire instrument to determine students' self regulated learning and test instruments to determine students' learning achievements. Data analysis techniques consist of descriptive analysis and inferential analysis. Descriptive analysis techniques calculate the percentage of students' questionnaire acquisition, calculate the gain of each research variable, maximum score, minimum score and error standard. While inferential analysis techniques test the research hypothesis using the Independent Samples $t$ Test to gain students' self regulated learning and learning achievements. Anava test toward the indicators of each variable and Tukey's test is the continuity of Anava. Normality test uses 
Kolmogorov-Smirnov and homogeneity test using Levene's test for equality variance. All data were analyzed using SPSS version 22 .

\section{Results And Discussion}

\subsection{Results}

Based on the research, it was obtained that students' self regulated learning in e-learning based schoology class before treatment (pretest) is $73.4 \pm 0.965$ and post-test is $88.33 \pm 0.482$ with a gain is $14.93 \pm 1.005$. While students' self regulated learning taught by power point (PPT) before treatment (pretest) is $73.76 \pm 0.855$ and the score after treatment (posttest) is $83.33 \pm 0.682$ with gain is $9.57 \pm 0.827$.

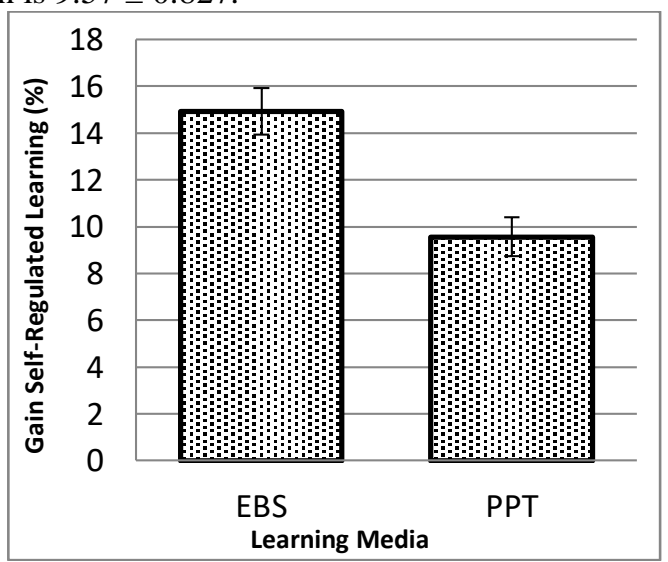

Fig 1. Comparison of students' self regulated learning taught by using e-learning based schoology (EBS) $(14.93 \pm 1.005)$ and power point media (PPT) $(9.57 \pm 0.827)$. Students' self regulated learning taught by EBS media is significantly higher than PPT $(\mathrm{P}=0,000)$

Based on the hypothesis test, it was obtained that students' self regulated learning is significantly higher at $21.88 \%$ compared to using power point (PPT) media (Figure 1). The analysis result of students' self regulated learning indicator shows that indicators of students' awareness toward learning goals, continuity of learning, and learning activities were significantly different. While indicators of awareness of learning responsibilities and learning efficiency do not show significant differences (Figure 2).

Based on the results of the variance data analysis on each indicator, it was obtained that students' self regulated learning are significantly different and the results of further tests with Tukey test shows that students' self regulated learning on indicators of students' awareness toward learning goals, learning responsibilities awareness, continuity of learning and elearning based schoology (EBS) is significantly different. While power point (PPT) gains students' self regulated learning on indicators toward learning goals awareness, continuity of learning and learning efficiency which are significantly different (Figure 2). 


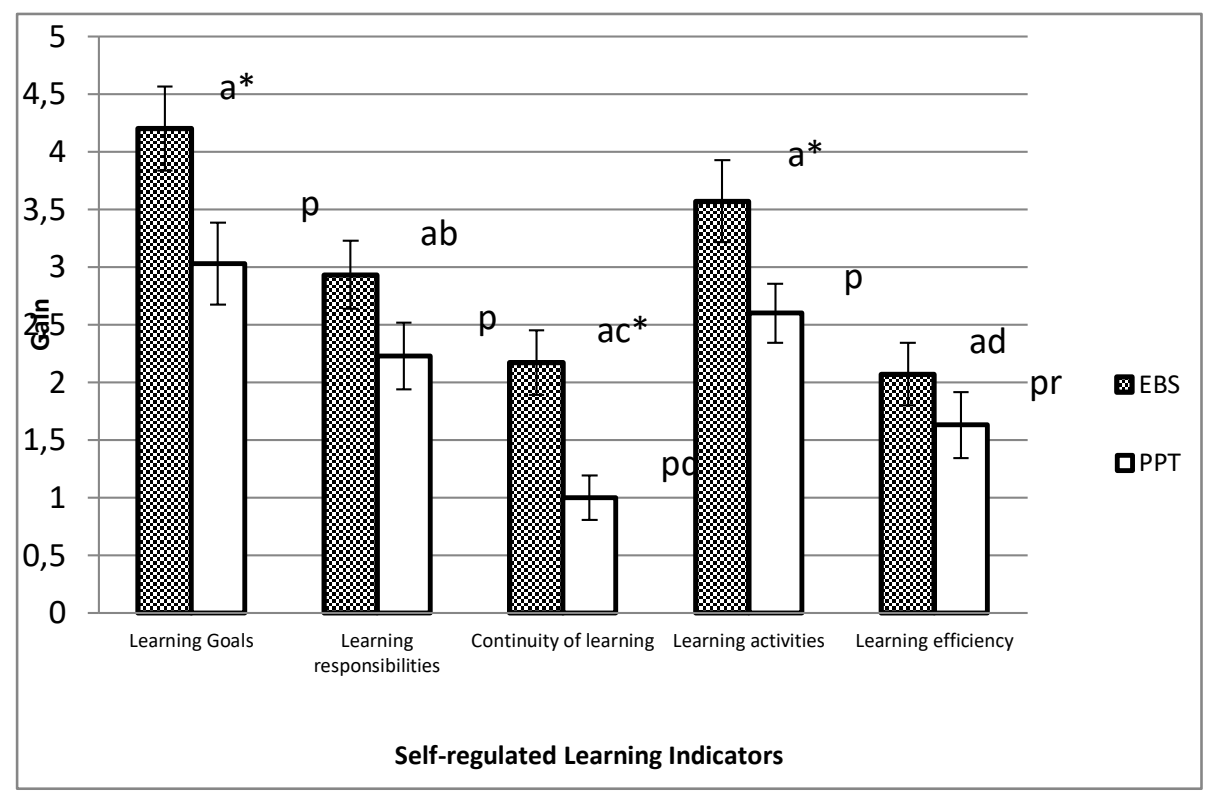

Fig 2. Comparison of the average gain of students' self regulated learning for each indicator taught using e-learning based schoology (EBS) and using power point media (PPT). The asterisk indicates a very significant difference compared to the pair on the same indicator $(\mathrm{P}=$ 0.026; $\mathrm{P}=0.001 ; \mathrm{P}=0.031$ in sequence). Different letters above the bar show significant difference compared to other indicators for the same media.

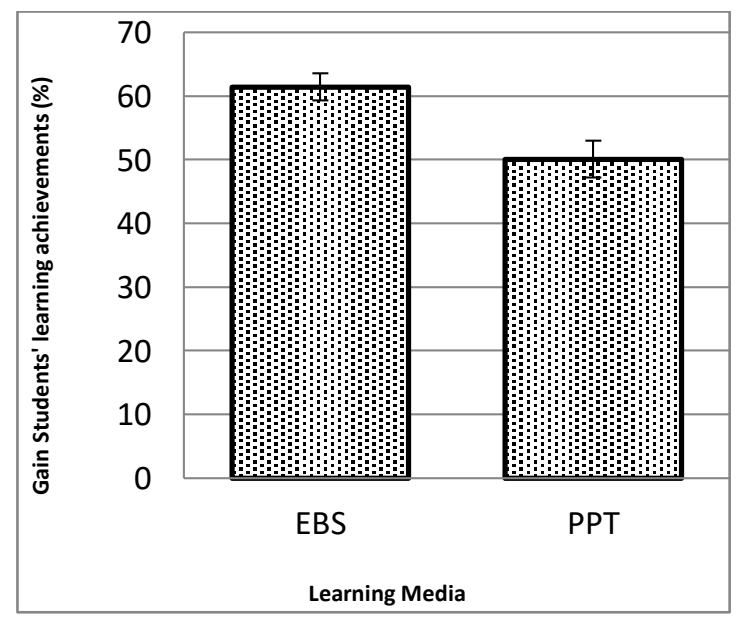

Fig.3. Gain comparison of students' learning achievements taught using e-learning based schoology media (EBS) $(61.44 \pm 2.138)$ and power point media (PPT) $(50.07 \pm 2.911)$. Students' learning achievements taught using EBS are significantly higher than PPT $(\mathrm{P}=$ 0.003) 
Based on the each indicator analysis toward students' learning achivements, it was obtained that indicators identify the structure, functions and processes which occur in the female reproduction organs, identify the process of gametogenesis, describe the process of fertilization and pregnancy shows significant differences. While indicators identify structures, functions and processes that occur in male reproduction organs, describe the menstruation process in women, connecting contraceptives and the process of preventing pregnancy in family planning and identifying diseases which occur in the human reproduction system do not show significant differences (Figure 4 ).

Based on the results of the analysis of variance data on each indicator, it is obtained that students' learning achievements differ significantly and the results of further tests with the Tukey test obtained that the learning achievements gain on indicators of male reproduction structure, fertilization and pregnancy, contraception and family planning, reproduction diseases humans in e learning based schoology (EBS) and power point (PPT) classes differ significantly (Figure 4).

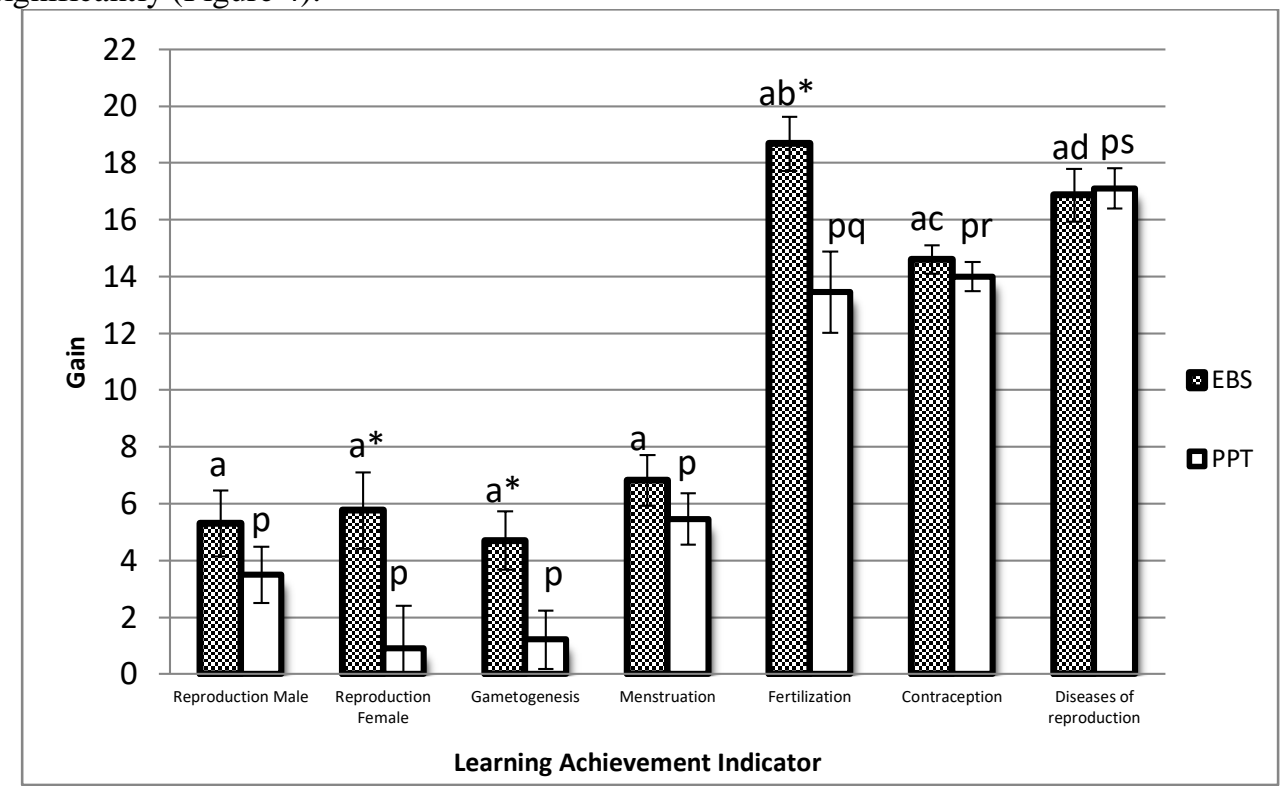

Fig 4. Comparison of the average gain of students' learning achievements for each indicator taught using e-learning based schoology media (EBS) and using power point media (PPT).

The asterisk indicates a very significant difference compared to the pair on the same indicator $(\mathrm{P}=0.019 ; \mathrm{P}=0.020 ; \mathrm{P}=0.004$ in sequence). Different letters above the bar show significantly different realities compared to other indicators for the same media

\subsection{Discussion}

The analysis of students' self regulated learning taught using e-learning based schoology is significantly higher than using power point media (Figure 1). One of the reasons of high students' self regulated learning in this e-learning based schoology is because when the learning process takes place, students are directly involved in finding information on topic discussed other than those which were already provided by the teacher. Students' interaction with this learning media was able to increase students' self regulated learning by seeing and 
paying attention to the material provided in e-learning based schoology, as well as students' interaction with students and teachers with students discussing each other. These results are supported by Hargis (2000) who states that online learning system can improve students' activity in learning and provide very high opportunities for students to successfully learn through internet. Because the more frequent students use internet technology, the more skillful the students are. This statement is supported by Dziuban et al (2004) in Cepik et al (2016) states that one of the characteristics of blended learning is to increase interaction among students and teachers, students with students, students with material and students beyond material. With this interaction, it causes an increasing on students' activity and students'self regulated learning to find information about the material being studied. Unlike the students in the power point class, the level of students' self regulated learning is lower because students are only involved in seeking additional information on the topic only from the students' handbook and asking teacher during the learning process. Therefore, the activity and self regulated learning conducted by students is less than the maximum in e-learning based schoology. Likewise when answering posttest questions, self regulated learning in the power point class is still less than optimal because it is still possible to ask friends and change answers on answer sheet. While in e-learning based on schoology, the possibility of asking and replacing answers can be minimized because in answering the posttest questions is done directly on the e-learning schoology website as well as computer-based test (CBT) and the results obtained can be directly checked by the teacher. This is what makes students' learning activities and self regulated learning different.

The activities of students involved in e-learning based schoology turned out to contribute to increase students' curiosity about what was being learned, both curiosity about the use of schoology and the material which is available in the media. This leads students' enthusiasm and learning activities to be high, especially because they learn new things via online and in line with technological developments in their day. As Santyasa (2003) stated, the atmosphere of e-learning learning can accommodate students to be more active in learning, students make design and look for material on their own. Likewise Lowry (2000) in Hidayati et al (2010) said that students' self regulated learning is a person's learning initiative with or without other people. In power point class, students' curiosity also increased, but students were not involved in using online technology so that students' activities and enthusiasm were not as high as elearning based schoology classes.

One of the criteria for students' self regulated learning according to Djamarah (2002) is students' learning activity. Based on the observations conducted by reserachers during the study, the learning activity of students using e-learning based schoology was higher than the class using power point media. This is due to e-learning based schoology class, students are involved in using technology such as computers, laptops and smartphones that are connected to the internet, which makes students directly involved in finding information on the material being studied. Whereas in the power point media class, students only see images displayed by the teacher through infocus. This difference in learning activity, apart from the results of the observations of the researcher, was also seen from the results of questionnaires which were filled by students on the indicator of learning activity in the e-learning schoology class compared to the power point class. This result is supported by Aminoto et al (2014) who found an increase in the average learning activity and students' learning achievements after using e-learning based schoology. Likewise Susanto et al (2011) used the blended learning method with media schoology to improve students' self regulated learning and Ansor (2015) also suggested that schoology was effective in increasing students' self regulated learning. 
Analysis of students' learning achievements data who were taught using e-learning based schoology was significantly higher than using power point media (Figure 3 ). The cause of higher learning achievements in e-learning based schoology class is this class makes learning more flexible, interesting, wider material discussed through video playback of embryo growth, animation of the birthing process, images in the form of power points and all word material Material formats can be downloaded so that they can be opened offline. This result is supported by Eison (2010) stated that the use of active learning can create students 'pleasure and increase students' knowledge. Students who enjoy learning lead to increasing of motivation and self regulated learning which has an impact on students' learning achievements. This acquisition can be seen from the score of students' learning achievements in the e-learning based schoology is higher than the class that uses power point who only see the picture through infocus. This result is in line with Dale's theory (1969) in the cone of his learning experience, stating that if students see images, videos and animations and discussion can improve students' learning experience by up to $50 \%$. While in the power point class, students only see pictures, listen to teacher explanations, find additional information from the handbook, discussion and question and answer which are all done face-to-face, based on the cone of Dale's experience (1969) this learning experience is only able to reach $30 \%$. With the difference in the format and form of material in the learning process that causes students' learning achievements that are taught by using e-learning based schoology is higher than the students' learning achievements in power point class.

Based on the observations of researchers during the research process, students who were taught using e-learning based schoology were more interested and enthusiastic during learning process, especially when playing embryonic growth videos. In the class of power point media, students were also enthusiastic in participating in learning, because during this slot, teachers rarely use e-learning media in teaching activities including power points, but what makes elearning based schoology class superior is because it can be done online, format material teaching is more varied, and it is more interactive so students experience a more dynamic learning process. This is considered to be something new for students to do in the learning process as a result students have a higher enthusiasm in participating in learning. While in power point class, it is only displayed the learning material in the form of images through infocus, so the learning process is not as dynamic as in e-learning based schoology. These results are supported by the findings of O'Day (2008) that animation is more effective than static sequential images in studying the concepts of biological material, and also Olson's findings (2011) suggested that the use of e-learning technology as a learning medium has shown high learning achievements. The enthusiasm of students is more visible when viewing videos, all students are very serious and no one is noisy. After the video is finished, many students ask questions about things they do not understand. From the questions raised by students, the teacher gives a more detailed explanation in order to provide a deeper understanding to students. Supported by the findings of Trisnawati (2014) high-level thinking skills of students who were taught to use camtasia media were better than students who were taught using power point media.

The use of instructional media both e-learning based schoology and power point media can extend and overcome material that is difficult for students to understand while learning in class, useful for developing and instilling student involvement in the learning process. It is supported by findings of Kafit (2009) using computer media can facilitate and improve the quality of learning, improve students' learning motivation, support individual learning in line with students' abilities, the material can be repeated as needed and able to improve students' learning achievement. However, the use of web-based online media provides more complete 
facilities that can be used by students to improve the quality of learning achievements compared to the use of offline media such as power points. Therefore the learning achievements obtained by students in e-learning based schoology are higher than the students' learning achievements in power point class. There are several advantages of learning using elearning media according to Dongsong et al (2004) in Monika (2013) which is studentcentered, students' self regulation, flexible time, can reach wider students, unlimited access. This result is supported by the research of Asandului et al (2008) students prefer learning with blended one. Likewise Bibi et al (2015) found that blended learning models effectively improve students' understanding, and Jethro et al (2012) said that students who get blended learning are better than students who do not use e-learning.

High motivation has a positive influence on self regulation, because motivation causes the emergence of competitive desire to advance for the good of him, initiative in learning and making decisions, having confidence in doing his tasks, responsible for what he does. The findings are supported by Sakinah's research (2013), there is a positive and significant relationship between self regulation and students' learning motivation. As a result of increasing students' self regulation because of high motivation causes students' learning achievements to be better and these results are supported by Budi et al (2012) research there is a significant relationship between students' self regulated learning and students' learning achievements. Likewise Khairunnisa (2015) found that self regulation has an effect on student learning achievements.

Thus, in this study students' learning achievements who are taught using e-learning based schoology are higher than students' learning achievements that are taught using power point media. These results are supported by the research undertaken by Kusumantara et al (2017) the learning achievements of students who use shoology are better than the results of the control class and Irawan et al (2017) also stated that there are significant differences in students' learning achievements between blended learning based schoology and problems based learning. Figure 4 Comparison of the average gain of students' learning achievements for each indicator taught using e-learning based schoology media (EBS) and using power point media (PPT). The asterisk indicates a very significant difference compared to the pair on the same indicator $(\mathrm{P}=0.019 ; \mathrm{P}=0.020 ; \mathrm{P}=0.004$ in sequence). Different letters above the bar show significantly different realities compared to other indicators for the same media

\section{Conclusion}

Based on the results and discussion presented, it can be concluded that students' self regulated learning who are taught using e-learning based schoology is significantly higher than students who were taught using power point media and students' achievements taught using e-learning based schoology are significantly high compared to students taught using power point media on the material of the human reproduction system in class XI Science at SMA Negeri 1 Silimakuta. In other words, the use of e-learning based schoology contributes more to increase students' self regulated learning and students' achievements compared to power point media, especially in the material of human reproduction system. Therefore, the researcher suggests the use of e-learning based schoology in biology learning process as a learning innovation. 


\section{References}

[1] Aminoto, T dan Pathoni. x Penerapan Media E-learning Berbasis Schoology Untuk Meningkatkan Aktivitas dan Hasil Belajar Materi Usaha dan Energi Di Kelas XI SMA N 10 Kota Jambi. Jurnal Sainmatika, 8(1): 45-53.((2004).

[2] Ansor, F.. Perbedaan Pengaruh Pemanfaatan Media E-learning berbasis Schoology dan Edmodo terhadap Kemandirian Belajar dan Prestasi Belajar Matematika. Jurusan Teknologi Pendidikan Universitas Sebelas Maret. Surakarta: Universitas Sebelas Maret.( 2015)

[3] Asandului, L dan Ceobanu, C.. E-learning in Romanian Higher Education: A Study Case. Turkish Online Journal of Distance Education, 9(3):162-17.(2008).

[4] Bibi, S dan Handaru, J.. Efektivitas Model Blended Learning terhadap Motivasi dan Tingkat Pemahaman Mahasiswa Mata Kuliah Algoritma dan Pemrograman. Jurnal Pendidikan Vokasi, 5(1): 74-87.( 2015)

[5] Budi, SS dan Rahma, W. 2012. Korelasi Antara Kreativias Belajar, Motivasi Belajar dan Kemandirian Belajar Siswa dengan Prestasi Belajar Keterampilan Elektronika di MAN I Wates Kabupaten Kulon Progo Tahun 2012. INSIGHT, 10 (1): 89-96.

[6] Cepik, Saban., Gönen K dan Sazak M K. (2016). ELT instructors' attitudes towards the use of Blended Learning in tertiary level English language programs. International Journal of Human Sciences, 13(1): 1716-1730.

[7] Cimer, A. (2012). What Makes Biology Learning Difficult and Effective: Students' Views. Journal Educational Research and Reviews, 7(3): 61-71.

[8] Dale, E. (1969). Audio Visual Methods in Teaching. New York: Holt, Rinehart and Winston Inc. The Dryden press.

[9] Djamarah, S B. 2002. Rahasia Sukses Belajar. Jakarta : Rineka Cipta.

[10] Eison, J. 2010. Using Active Learning Instructional Strategies to Create Excitement and Enhance Learninimerg. Department of Adult, Career \& Higher Education. Florida: University of South Florida.

[11] Hargis, J. (2000). The Self-Regulated Learner Advantage: Learning Science on the Internet. Electronic Journal of Education, 4(4).

[12] Hidayati, K dan Listyani, E. 2010. Pengembangan Instrumen Kemandirian Belajar Mahasiswa. Jurnal Penelitian dan Evaluasi Pendidikan, 14 (1): 84-100.

[13] Horton, W dan Horton, K. (2003). E-learning Tools and Technologies: A consumer guide for trainers, teachers, educators, and instructional designers. USA : Wiley Publishing, Inc.

[14] Irawan, V T., Eddy Sutadji dan Widiyanti. (2017). Blended Learning Based on Schoology: Effort of Improvement Learning Outcome and Practicum Chance in Vocational High School. Curriculum \& Teaching Studies Research Article. Journal Cogent Education, 4: 1282031 .

[15] Isparmo. (2016). Data Statistik Pengguna Internet Indonesia Tahun 2016.http://isparmo.web.id/2016/11/21/data-statistik-pengguna - internet indonesia-2016/, diakses tanggal 19 Januari 2017

[16] Jethro, O O., Grace, A M dan Thomas, A K. 2012. E-learning and its Effects on Teaching and Learning in a Global Age. International Journal of Academic Research in Business and Social Sciences, 2(1): 203-210.

[17] Kafit, M. 2009. Efektifitas Penggunaan Media Pembelajaran Komputer untuk Meningkatkan Hasil Belajar Mata Pelajaran IPA Kelas VIII MTS NU Hasym Asy'ari 03 Honggosoco Jekulo Kabupaten Kudus. Tesis PPS Universitas Sebelas Maret. Surakarta: UNS. 
[18] Khairunnisa, R. 2015. Pengaruh Kemandirian Belajar terhadap Hasil Belajar pada Mata Pelajaran Ekonomi. Jakarta: UPI.

[19] Kusumantara, K.S., Gede, S.S dan Nyoman, S. 2017. Pengaruh E-learning Schoology terhadap Hasil Belajar Simulasi Digital dengan Model Pembelajaran Savi. Jurnal Pendidikan Teknologi dan Kejuruan, 14(2):126.

[20] Mavrikaki, E., Koumparou H., Kyriakoudi M., Papacharalampous I dan Trimandili M. (2012). Greek Secondary School Students' Views About Biology. International Journal of Environmental \& Science Education. 7(2): 217-232.

[21] Monika, C. 2013. Analysis of Perceptions of Conventional and E-learning Education in Corporate Training. Journal of Competitiveness, 5 (4): 73-97.

[22] O’Day, D.H. (2008). Using Animations To Teach Biology: Past \& Future Research on the Attributes that Underlie Pedagogically Sound Animations. Jurnal The American Biology Teacher, 70(5):274-278.

[23] Olson, J; Codde, J., deMaagd, K., Tarkelson, E., Sinclair, J., Yook, S dan Egidio, R. 2011. An Analysis of E-learning Impacts \& Best Practices in Developing Countries With Reference to Secondary School Education in Tanzania. Communication Arts \& Sciences Building Michigan State University: USA.

[24] Ozcan, T., Ozgur S., Aybuke K dan Elgun S. (2014). Identifiying and Comparing the Degree of Difficulties Biology Subjects By Adjusting It is Reasons in Elemantary and Secondary Education. Journal Elsevier Procedia - Social and Behavioral Sciences, 116 (2014): $113-122$

[25] Sakinah, SY. 2013. Hubungan Antara Kemandirian Belajar (Self Directed Learning) dengan Motivasi Belajar pada Mahasiswa Universitas Esa Unggul. Tesis Fakultas Psikologi UEU. Jakarta: UEU.

[26] Santyasa, I. W. 2013. Pengaruh Model E-learning Berbasis Masalah dan Motivasi Belajar Terhadap Hasil. Fakultas MIPA UNS. Semarang: UNS

[27] Sicat, AS dan Ed, MA. (2015). Enhancing College Students' Proficiency in Business Writing Via Schoology. International Journal of Education and Research, 3 (1):159-178.

[28] Srimaya. 2017. Efektivitas Media Pembelajaran Power Point untuk Meningkatkan Motivasi dan Hasil Belajar Biologi Siswa. Jurnal Biotek, 5 (1): 53-68.

[29] Sugiyono. 2015. Metode Penelitian Manajemen Pendekatan Kuantitatif, Kualitatif, Kombinasi, Penelitian Tindakan, Penelitian Evaluasi. Bandung: Alfabeta.

[30] Susanto, D F dan Paseleng, M C. 2011. Penggunaan Metode Blended Learning dengan Media Schoology untuk Meningkatkan Self Regulated Learning Siswa X RPL 1 SMKN 1 Tengaran. Fakultas Teknologi Informasi. Salatiga: Universitas Kristen Satya Wacana.

[31] Tekkaya, C., Ozkan O dan Sungur S. (2001). Biology Concepts Perceived As Difficult By Turkish High School Students. Hacettepe Üniversitesi Eğitim Fakültesi Dergisi 21: 145150.

[32] Trisnawati, G. 2014. Perbandingan Penggunaan Media Pembelajaran Camtasia dan Power point dengan Penerapan Strategi Pembelajaran Langsung terhadap Kemampuan Berpikir Tingkat Tinggi dan Retensi Memori Biologi Siswa Kelas X SMA N 12 Medan. Tesis Pascasarjana Pendidikan Biologi. Medan: Universitas Negeri Medan.

[33]Wahono, RS. (2003). Pengantar E-learning dan Pengembangannya. www.ilmukomputer.com, diakses tanggal 9 Mei 2016.

[34]Wood, W B. 2009. Innovations in Teaching Undergraduate Biology and Why We Need Them. Department of Molecular, Cellular, and Developmental Biology, University of Colorado. Colorado: University of Colorado. 